\title{
Characterization of Propionispira arboris gen. nov. sp. nov., a Nitrogen- fixing Anaerobe Common to Wetwoods of Living Trees
}

\author{
By BERNHARD SCHINK, $†$ THOMAS E. THOMPSON AND J. G. ZEIK US* \\ Department of Bacteriology, University of Wisconsin, Madison, Wisconsin 53706, U.S.A.
}

(Received 8 February 1982; revised 30 April 1982)

\begin{abstract}
A new species in the family Bacteroidaceae is described, isolated from alkaline wetwoods of poplar trees. It was a non-sporing, curved rod that formed long spiral filaments, especially when grown with $\mathrm{N}_{2}$ as the sole nitrogen source. This obligate anaerobe had peritrichous flagellation and an outer-wall membranous layer. The DNA G $+\mathrm{C}$ content was $36.7 \pm 1.0 \mathrm{~mol} \%$. Cell extracts displayed absorption peaks for type $b$ cytochromes in oxidized versus reduced difference spectra. Nitrogenase was detected by acetylene reduction in cells grown on glucose in the absence of combined nitrogen. This species fermented lactate and a variety of saccharides. Propionate, acetate and $\mathrm{CO}_{2}$ were major products, with succinate and ethanol formed in trace quantities. The optimal $\mathrm{pH}$ and temperature for growth were $6 \cdot 0-6.5$ and $30-33^{\circ} \mathrm{C}$, respectively. The name Propionispira arboris gen. nov. sp. nov. is proposed for the type strain 12B4, which has been deposited as ATCC 33732.
\end{abstract}

\section{INTRODUCTION}

Most descriptions of Gram-negative, helical to spiral shaped, chemoorganotrophic rods concern aerobic Spirillum species (Buchanan \& Gibbons, 1974). In addition, an aerobic nitrogen-fixing genus, Azospirillum, has been recognized (Tarrand et al., 1978), and studies of obligately anaerobic organisms have resulted in the descriptions of Anaerobiospirillum (Davis et al., 1976) and Methanospirillum (Ferry et al., 1974) both with polar flagellation, and Pectinatus with lateral comb-like flagellation (Lee et al., 1978). Both Anaerobiospirillum succiniciproducens (Davis et al., 1976) and Pectinatus cerevisiiphilus (Lee et al., 1978) ferment carbohydrates; however, the former produces succinate and the latter propionate as the major fermentation end product.

Recently, the wetwood disease syndrome of living hardwood trees has been attributed to high population densities [i.e. $\sim 10^{7}$ cells (g wood) $)^{-1}$ ] of anaerobic bacteria (Schink et al., $1981 a, b$ ). Important metabolic activities expressed by wetwood anaerobes included methanogenesis (Zeikus \& Ward, 1974), nitrogen fixation (Schink et al., 1981a) and pectinolysis (Schink et al., $1981 \mathrm{~b}$ ). Moreover, a wide diversity of bacteria can be isolated from wetwoods; the prevalent chemoorganotrophs include Bacteroides, Clostridium, Erwinia, Edwardsiella, Klebsiella and Lactobacillus species (Schink et al., 1981a).

The present study describes a new species of obligately anaerobic, Gram-negative, helicalshaped rods that are commonly enriched from alkaline wetwoods in a carbohydrate medium devoid of combined nitrogen.

\section{METHODS}

Chemicals. All chemicals used were reagent grade and were obtained from either Mallinckrodt (Paris, Ky., U.S.A.) or Sigma. Pectin was a gift of Sunkist Growers (Corona, Calif., U.S.A.). Agar, tryptone and yeast extract were obtained from Difco. All gases were obtained from Matheson (Joliet, Ill., U.S.A.) and were purified free of oxygen by passage over heated $\left(370^{\circ} \mathrm{C}\right)$ copper filings.

Inocula and bacterial strains. Wetwood inocula were obtained from various cottonwood trees (Populus deltoides

† Present Address: Facultat für Biologie, Universität Konstanz, Postfach 5560, D-775 Konstanz, F.R.G. 
Bartr.) located in Wisconsin, U.S.A. A wetwood sample obtained from the largest cottonwood tree in Columbus, Wisconsin, was used for enrichment and isolation of strain 12B4. Procedures for anaerobic sampling and processing of wetwood were as described previously (Zeikus \& Ward, 1974; Schink et al., 1981a). Pectinatus cerevisiiphilus strain CCCB-1022 was obtained from Dr Sharon Moore, Adolph Coors, Golden, Colo., U.S.A.

Culture techniques and media. Anaerobic procedures used for cell cultivation and media preparation were as described previously (Zeikus et al., 1980; Schink et al., 1981 a). The low phosphate buffered basal medium (LPBB medium) described by Zeikus et al. (1979) was used, with a $\mathrm{N}_{2} / \mathrm{CO}_{2}(95: 5)$ gas phase. When needed, carbohydrates $(0.5 \%, \mathrm{w} / \mathrm{v})$, tryptone $(1 \%, \mathrm{w} / \mathrm{v})$ or yeast extract $(0.3 \%, \mathrm{w} / \mathrm{v})$ were autoclaved separately and added by syringe to the final concentrations indicated. The medium of $\mathrm{Ng}$ et al. (1977) was used to examine cellulose fermentation, and medium 77 (Postgate, 1963) was used to test sulphate reduction. Ammonium chloride was omitted from LPBB medium when cells were examined for nitrogen fixation. Routine cell maintenance and experimental analyses were performed in anaerobic culture tubes $(23 \mathrm{ml}$ volume, $18 \times 142 \mathrm{~mm}$; Bellco Glass, Vineland, N.J., U.S.A.) containing $10 \mathrm{ml}$ medium, and sealed with black rubber bungs. Prior to inoculation, culture medium was reduced by the addition of sodium sulphide $(0.05 \%, \mathrm{w} / \mathrm{v}$ final concentration). For isolation of colonies in either anaerobic roll tubes or in Petri dishes maintained in an anaerobic chamber (Coy Products, Ann Arbor, Mich., U.S.A.) LPBB medium was supplemented with $0.5 \%(\mathrm{w} / \mathrm{v})$ glucose, $0 \cdot 1 \%(\mathrm{w} / \mathrm{v})$ yeast extract and $2.0 \%(\mathrm{w} / \mathrm{v})$ purified agar. Large quantities of cells were grown in glass carboys that contained $151 \mathrm{LPBB}$ medium, $0.5 \%$ glucose and $0.1 \%$ yeast extract. Cultures were routinely incubated without shaking at $30^{\circ} \mathrm{C}$ unless indicated in the text.

Cellular characterization. A Carl Zeiss photomicroscope was used for phase-contrast and bright-field observations including determination of cell size. Agar-coated glass slides were used to obtain long spiral filaments in focus for photomicroscopy. Flagella were stained by the techniques of Mayfield \& Inniss (1977) and examined by phase-contrast microscopy.

The preparation of cells for thin sectioning and electron microscopy was as described by Zeikus \& Bowen (1975). For analysis of carbohydrate storage material in cells, the techniques of Hanker (1964) were used prior to thin sectioning. The procedures described by Ben-Bassat \& Zeikus (1981) were used for negative staining. All preparations were examined with a Hitachi HU $11 \mathrm{E}$ electron microscope.

DNA was isolated and purified from lysozyme-treated cells by the method of Marmur (1961). DNA base compositions were calculated according to the method of DeLey (1970) in 0.015 $\mathrm{M}-\mathrm{NaCl}$ and $0.0015 \mathrm{M}$-trisodium citrate as determined in a Gilford model 250 spectrophotometer equipped with a model 2527 thermoprogrammer. Escherichia coli DNA VIII (lot no. 57C-6830, Sigma) served as standard. DNA composition reported represents the mean of four separate determinations. The percentage $\mathrm{G}+\mathrm{C}$ of the $E$. coli standard was $52.8 \pm 1.0 \%$.

Cytochromes were identified in air versus dithionite-reduced difference spectra of cell extracts analysed with a Beckman model 25 scanning spectrophotometer. Cell extracts were prepared by sonicating a suspension of $1 \mathrm{~g}$ wet weight cells in $5 \mathrm{ml} 50 \mathrm{~mm}$-potassium phosphate buffer and retaining the supernatant after centrifugation at $10000 \mathrm{~g}$ for $15 \mathrm{~min}$ in a Sorvall centrifuge. Protein was determined by the Lowry method.

Growth and metabolic characterization. Growth was determined by measuring the increase in turbidity at $660 \mathrm{~nm}$. Absorbance was estimated directly by insertion of the anaerobic culture tubes into a Spectronic 20 spectrophotometer (Bausch \& Lomb).

Growth on various substrates was examined in liquid cultures after one week of cultivation. Physiological reactions were determined by use of assay kits (API Systems 20E and 20A; Analytab Products, Plainview, N.Y., U.S.A.).

Fermentation products were measured directly in liquid or gas samples removed from the culture tubes by syringe. Alcohols and acids were measured by gas chromatography using a flame ionization detector as described by Zeikus et al. (1979). All gases were quantified by the gas chromatography-thermal conductivity detection methods of Nelson \& Zeikus (1974). A Perkin Elmer Series 3 high-performance liquid chromatograph with a BioRad organic acid analysis column (no. 125-0140) was used to detect succinate. Lactate was measured spectrophotometrically by the D- or L-lactate dehydrogenase assay procedure of Bergmeyer (1965). Glucose consumption was determined by reducing sugar analysis with dinitrophenylsalicylic acid (Miller et al., 1960).

Nitrogen fixation was determined by the acetylene reduction test (Stewart et al., 1967). Late-exponential phase grown cells were gassed with $\mathrm{N}_{2} / \mathrm{CO}_{2}(95: 5, \mathrm{v} / \mathrm{v})$ and $0.4 \mathrm{ml}$ acetylene was added to each experimental culture tube. The formation of ethylene with time was detected by the gas chromatography-flame ionization detection methods of Nelson \& Zeikus (1974).

\section{RESULTS}

\section{Isolation and cultivation}

The organism was selectively enriched from alkaline wetwoods of mature cottonwood trees in LPBB medium that contained pectin as the energy source. When the enrichment culture fluid 
was examined by phase-contrast microscopy it contained some curved rods that moved very fast, and in a manner characteristic of Spirillum species. Transfer of primary enrichments to arabinose/LPBB medium without combined nitrogen greatly enhanced cell numbers relative to other species. The organism was then readily isolated by dilution in agar roll tubes and by picking and re-streaking individual colonies. Colonies developed rapidly (1-2 d) on LPBB $/ 0.5 \%$ glucose $/ 0.1 \%$ yeast extract agar plates in the anaerobic glove box chamber. Colonies were uniformly round and became light brown when stored. Stock cultures were maintained on LPBB $/ 0 \cdot 5 \%$ sodium lactate $/ 0 \cdot 1 \%$ yeast extract medium, and transferred weekly. Liquid cultures lost viability after 2 weeks' storage. Permanent stocks were kept for more than 6 months by freezing anaerobic cell suspensions in $20 \%(\mathrm{v} / \mathrm{v})$ glycerol at $-80^{\circ} \mathrm{C}$.

\section{Cellular properties}

Exponential phase cultures appeared as actively motile curved rods when observed microscopically (Fig. 1a). Long spiral cell filaments were readily observed in cultures growing in the absence of combined nitrogen (Fig. $1 b$ ) or in late-exponential phase cultures grown in the presence of ammonium. Spores were not observed and old cultures became granular before cell lysis occurred. The cells stained Gram-negative and lacked catalase. Growth was inhibited by cycloserine, penicillin, streptomycin, tetracycline or chloramphenicol (each at $100 \mu \mathrm{g} \mathrm{ml}^{-1}$ );2\% $\mathrm{NaCl}$; and sodium azide $\left(500 \mu \mathrm{g} \mathrm{ml}^{-1}\right)$.

Stained cells observed by bright-field microscopy showed peritrichous flagellation. This was confirmed by transmission electron microscopic analysis of negatively stained cells (Fig. $2 a, b$ ). Control preparations with Pectinatus cerevisiiphilus showed flagellar insertion only on the concave side of the cells. In thin sections (Fig. $3 a, c$ ) a typical Gram-negative cell architecture comprising an outer-wall membrane and a poorly discernible inner-wall layer was evident. Granular cytoplasmic inclusions were confirmed as carbohydrate reserve material by specific staining (Fig. $3 b$ ). The base composition of the DNA was $36.7 \pm 1.0 \mathrm{~mol} \% \mathrm{G}+\mathrm{C}$. Difference spectra of crude cell extracts indicated the presence of a type $b$ cytochrome with $\alpha, \beta$ and $\gamma$ bands at $560-562,530-535$ and $429 \mathrm{~nm}$ respectively (Fig. 4).

\section{Growth and metabolic properties}

The organism displayed the cardinal growth temperatures of a mesophile with an optimum of $30-35^{\circ} \mathrm{C}$, and no growth was observed above $45^{\circ} \mathrm{C}$ or below $4{ }^{\circ} \mathrm{C}$. The optimum pH for growth in LPBB medium with $0.5 \%$ glucose was $6.0-6.5$, and no growth was detected below 4.5 or above $8 \cdot 0$.

A wide variety of compounds were fermented, including arabinose, cellobiose, galactose, glucose, lactose, mannose, mannitol, raffinose, galacturonate, sorbitol, sucrose, glycerol, lactate and amygdalin. Inositol, maltose, melibiose, melezitose, rhamnose, trehalose, arabinogalactan, cellulose, mannose, pectin, polygalacturonic acid, starch, xylan, citrate, pyruvate, tartrate, aesculin, salicin, Casamino acids, gelatin and tryptone were not fermented.

The growth rate of the organism was dependent on both the specific energy source and the nutrient nitrogen source (Fig. 5). The specific growth rate $(\mu)$ was much higher on glucose in complex media $\left(0.18 \mathrm{~h}^{-1}\right)$ than on ammonium chloride $\left(0.13 \mathrm{~h}^{-1}\right)$ or $\mathrm{N}_{2}\left(0.03 \mathrm{~h}^{-1}\right)$. Notably, the growth rate on LPBB medium with $0.5 \%$ sodium lactate and $\mathrm{N}_{2}$ as nitrogen source was only $0.003 \mathrm{~h}^{-1}$. The cell yield on any substrate tested was highest in complex medium and lowest when $\mathrm{N}_{2}$ was the sole source of nitrogen. Cultures grown on glucose in LPBB medium with $\mathrm{N}_{2}$ alone exhibited an acetylene reducing activity of 5-21 nmol ethylene formed h-1 $\mathrm{ml}^{-1}\left(A_{660}\right.$ was $0 \cdot 35$ ). The addition of ammonium chloride to cultures inhibited nitrogenase activity. Neither growth with $\mathrm{N}_{2}$ as the sole nitrogen source nor acetylene reduction activity was detected in control experiments with Pectinatus cerevisiiphilus.

The main products of carbohydrate fermentation were propionate, acetate and $\mathrm{CO}_{2}$. Ethanol and succinate were only formed in trace quantities when glucose was fermented (Table 1). However, ethanol was a more significant end product of xylose metabolism, and succinate was a 

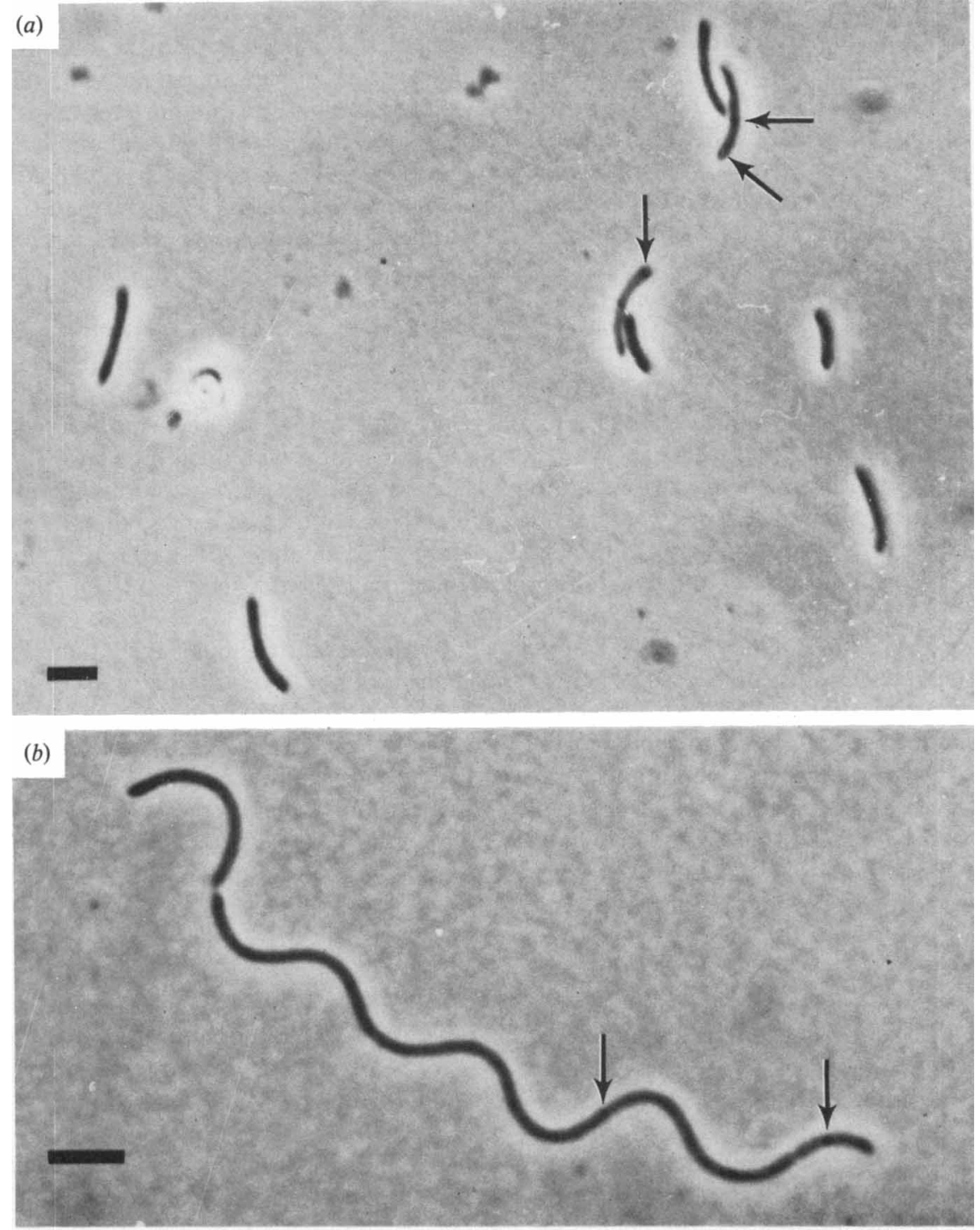

Fig. 1. Phase-contrast photomicrographs of strain 12B4. (a) Exponential phase cells grown on LPBB medium with glucose $(0.5 \%)$ and yeast extract $(0 \cdot 1 \%)$. Arrows point to granular reserve material. $(b) \mathrm{A}$ spiral shaped cell present in an exponential phase culture grown in LPBB medium with $0.5 \%(w / v)$ sodium lactate and $\mathrm{N}_{2}$ as sole nitrogen source. The bar markers represent $5 \mu \mathrm{m}$.

major end product when fumarate was added to glucose/LPBB medium. Neither $\mathrm{H}_{2}$, lactate nor other soluble or gaseous compounds were detectable fermentation products.

The dependence of end product formation on growth is shown in Fig. 6. At the end of the time course the fermentation balance measured was

$227 \mathrm{nmol}$ glucose $\rightarrow 300 \mathrm{nmol}$ propionate $+161 \mathrm{nmol}$ acetate $+142 \mathrm{nmol} \mathrm{CO}$

This accounted for a carbon recovery of $100 \%$ and an oxidation-reduction index of 0.95 . 


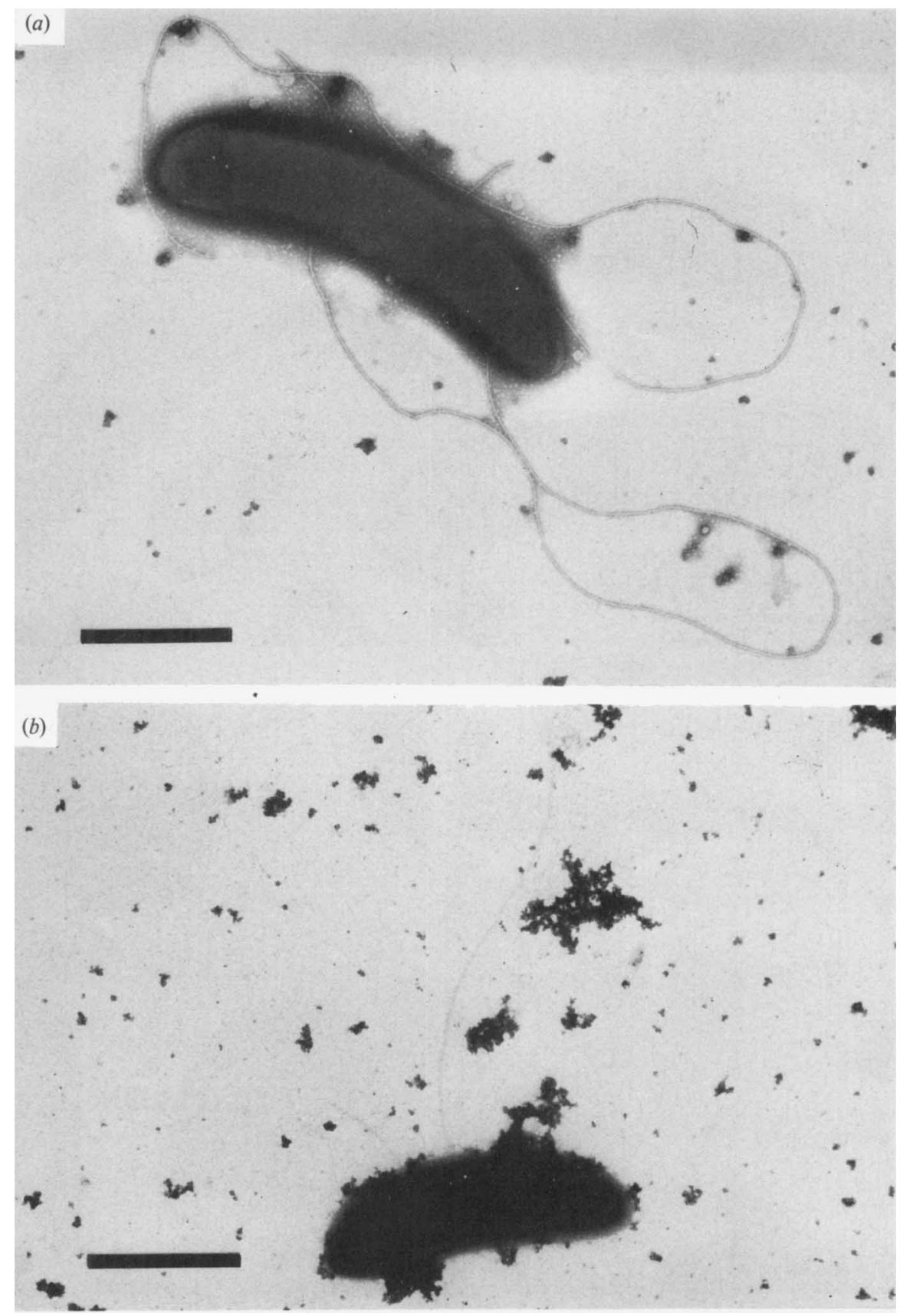

Fig. 2. $(a, b)$ Electron micrographs of phosphotungstic acid stained cells showing random flagella placement of strain 12B4. The bar markers represent $1 \mu \mathrm{m}$.

\section{DISCUSSION}

The isolation of this bacterium extends the diversity of known obligately anaerobic bacteria. These spiral-shaped cells could be regarded as the anaerobic counterpart to Spirillum lipoferum, the aerobic nitrogen-fixing curved rods first reported by Beijerinck (1925). Although this aerobic 

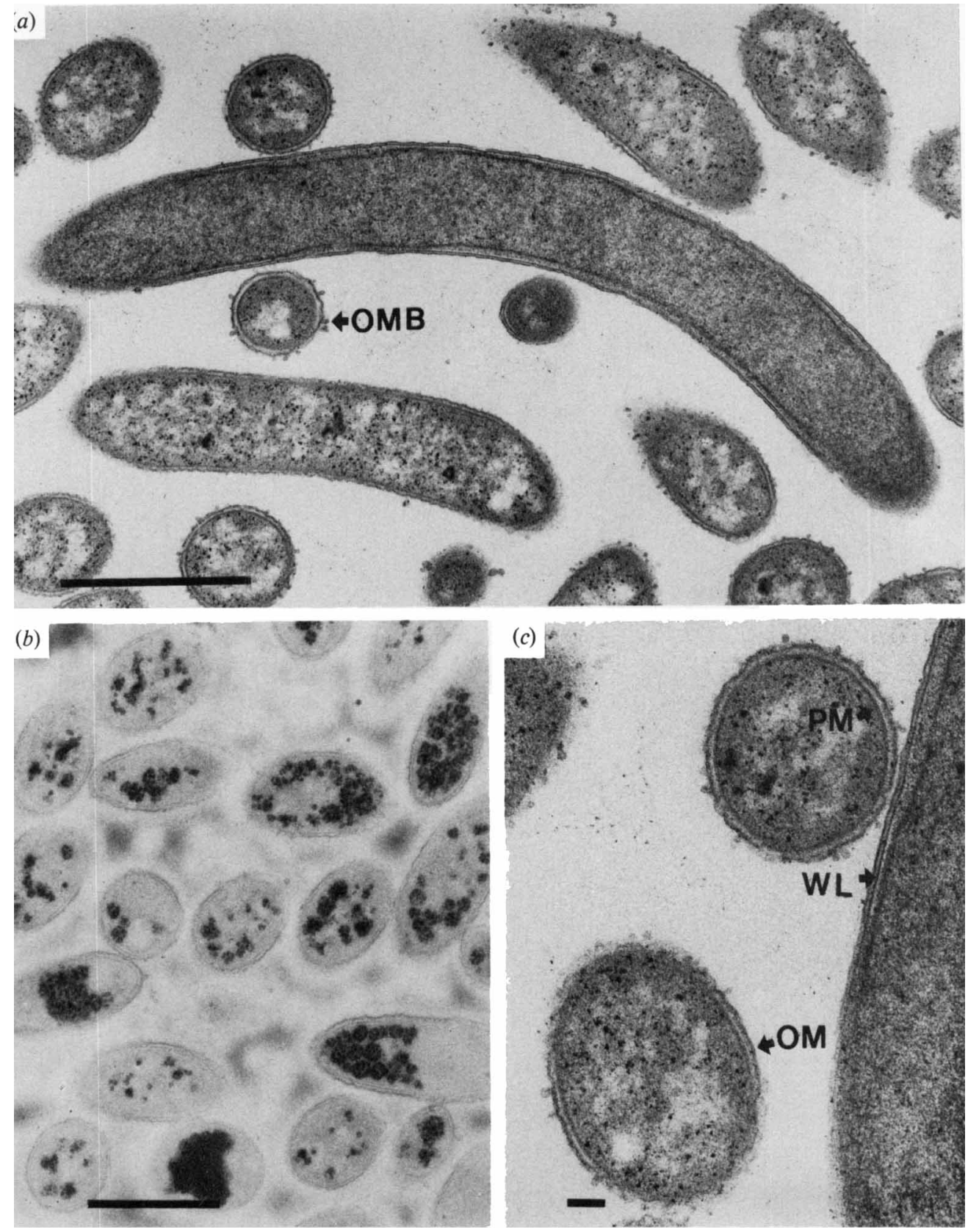

Fig. 3. Electron micrographs of strain 12B4 thin sections. (a) Grazing sections of cells showing general ultrastructural features and outer membranous blebs (OMB). (b) Cells showing carbohydrate storage material after specific staining and fixation procedures. $(c)$ High magnification illustrating typical Gram-negative cell wall ultrastructure including outer membranous wall layer (OM), inner wall layer (WL) and the cytoplasmic membrane (PM). The bar markers represent $1 \mu \mathrm{m}$ in $(a)$ and $(b)$ and $0 \cdot 1 \mu \mathrm{m}$ in (c).

species is now recognized as Azospirillum lipoferum (Tarrand et al., 1978), it also contained granular storage material. However, the bacterium described here is an obligate anaerobe and forms a carbohydrate reserve material, not poly- $\beta$-hydroxybutyric acid. 


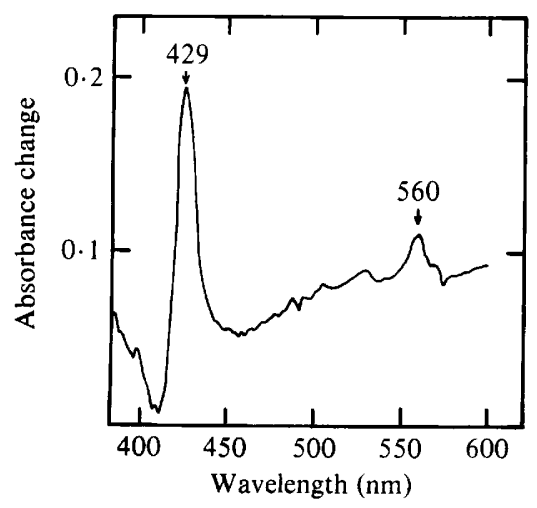

Fig. 4. Sodium dithionite-reduced versus air-oxidized difference spectrum of crude extract of strain 12B4. The protein content of the preparation was $2 \cdot 2 \mathrm{mg} \mathrm{ml}^{-1}$.

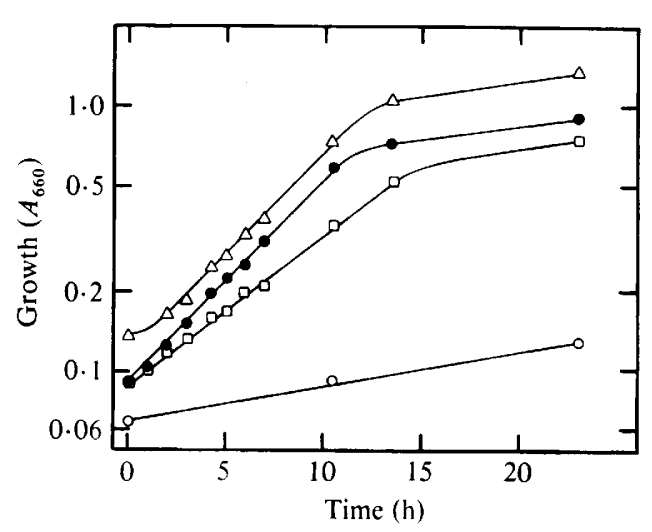

Fig. 5

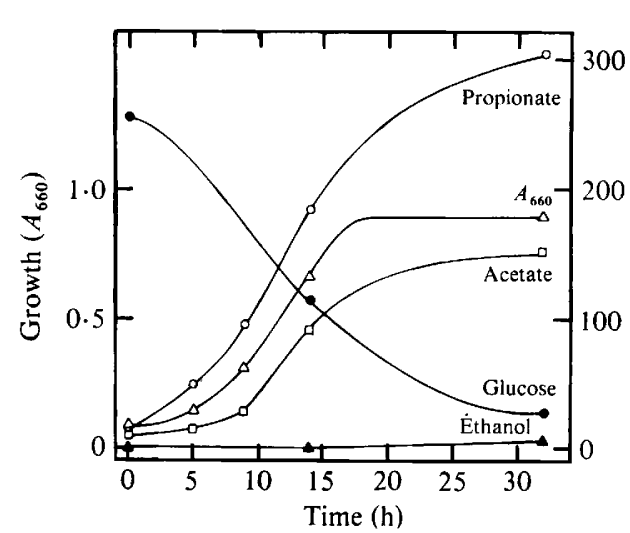

Fig. 6

Fig. 5. Relation between medium nitrogen sources and growth of strain 12B4 on glucose. $\triangle$, LPBB + $1 \%(w / v)$ tryptone $+0.3 \%(w / v)$ yeast extract;, LPBB $+0.3 \%(w / v)$ yeast extract; $\square, L P B B ; O$, LPBB with $\mathrm{N}_{2}$ as sole nitrogen source.

Fig. 6. Glucose fermentation time course for strain 12B4. Experiments were performed in anaerobic culture tubes that contained $10 \mathrm{ml} \mathrm{LPBB}$ and $0.5 \%(\mathrm{w} / \mathrm{v})$ glucose.

Table 1. Relation between energy source and end products formed by strain 12B4

Experiments were done in anaerobic culture tubes that contained $10 \mathrm{ml}$ LPBB medium. Substrate concentrations (mM) added were: glucose, 25; arabinose, 33; xylose, 33; lactate, 90 and fumarate, 40.

\begin{tabular}{lcccc}
\multicolumn{1}{c}{ Substrate } & \multicolumn{3}{c}{ Fermentation products (total $\mu$ mol per tube) } \\
\cline { 2 - 6 } Ethanol & Acetate & Propionate & Succinate \\
Arabinose & 6 & 203 & 370 & ND \\
Xylose & 47 & 156 & 280 & ND \\
Lactate & 8 & 255 & 460 & ND \\
Glucose & $<1$ & 161 & 300 & $<1$ \\
Glucose/fumarate & $<1$ & 240 & 400 & 356
\end{tabular}

ND, Not determined.

This is the first report of a propionic acid-forming anaerobe able to fix nitrogen. At present, two pathways are recognized for the formation of propionic acid (Zeikus, 1980). Propionibacterium and Selenomonas species utilize fumarate as an intermediary metabolite, whereas Bacteroides, Megasphaera and Clostridium species utilize acrylyl-CoA. The fermentation balance for the new isolate was very close to classical propionibacteria results; namely, 3 glucose $\rightarrow 4$ propionate +2 acetate $+2 \mathrm{CO}_{2}$. The Propionibacterium-Selenomonas pathway is suggested for 
strain 12B4 for the following reasons. First, hydrogen was not detected as an end product. Secondly, fumarate addition greatly stimulated propionate formation during glucose fermentation. Lastly, a type $b$ cytochrome was identified which is the same as that reported in Propionibacterium (de Vries et al., 1973; Schwartz \& Sporkenbach, 1975) and Selenomonas (de Vries et al., 1974).

The physiological properties of the bacterium reported here suggest that it is well-adapted to the wetwood ecosystem. Alkaline wetwoods are notably anaerobic, low in fixed nitrogen, abundant in saccharides and contain numerous bacterial fermentation products including propionate (Zeikus \& Ward, 1974; Schink et al., 1981a). This bacterium can ferment a variety of wood sugars including galacturonate released by pectinolytic activity (Schink et al., 1981 a), and under the nitrogen-fixing conditions (Schink et al., 1981 a) associated with the wetwood disease syndrome in living trees. This organism may therefore function in the supply of fixed nitrogen to other wetwood species and account in part for the formation of propionate in this novel microbial ecosystem, which also contains Methanobacterium arbophilicum (Zeikus \& Henning, 1975).

The cellular and metabolic properties of the bacterium suggest that it may be affiliated to the family Bacteroidaceae (Buchanan \& Gibbons, 1974). However, since it forms only propionate, acetate, $\mathrm{CO}_{2}$ and traces of succinate and ethanol, generic assignment to Bacteroides, Fusobacterium, Leptotrichia, Butyrivibrio, Succinivibrio, Succinimonas, Lachnospira, Selenomonas or Anaerobiospirillum is not possible. It differs dramatically from propionate-forming Selenomonas species by its low DNA G + C content (36.7 versus $53-61 \%$ ) and peritrichous flagellation, and bears closest resemblance to Pectinatus cerevisiiphilus. However, the latter produces lactate and succinate from glucose, has a DNA G + C content of $39.8 \%$ and has a 'comb-like' insertion of flagella only on the concava side of the cell (Lee et al., 1978). Moreover, Pectinatus cerevisiiphilus does not fix nitrogen or grow in a mineral medium on amygdalin, lactose, sorbitol or sucrose. Nonetheless, further macromolecular taxonomic studies are needed on the generic designations of these two species.

The catabolic activity of this bacterium may be of industrial interest. For example, the organism, unlike Propionibacterium species, can grow without vitamins, yeast extract and, if necessary, ammonium. Perhaps this could be of importance to the production of vitamin $\mathbf{B}_{12}$ or propionic acid.

\section{Propionispira arboris gen. nov. and sp. nov.}

Pro.pi.o.ni.spi.ra. M.L. n. acidum propionicum propionic acid, L. fem.n. spira coil L. fem.n. arbor tree, arboris of a tree.

Morphology. Curved to helical rods $1 \times 7 \mu \mathrm{m}$. Exponential-phase cells very motile by peritrichous flagellation. Forms long spiral cells when grown under $\mathrm{N}_{2}$-fixing conditions. Gramnegative and endospores not formed. Colonies on agar surfaces are smooth and 1-3 nm in diameter.

Cellular characteristics. DNA base composition of $36 \cdot 7 \pm 1 \mathrm{~mol} \% \mathrm{G}+\mathrm{C}$. Cytochrome $b$ and nitrogenase are present and catalase is absent. Double-layered cell wall architecture with outer wall membrane present.

Growth characteristics. Optimum temperature for growth is $30-35^{\circ} \mathrm{C}$, maximum $<46^{\circ} \mathrm{C}$ and minimum $>4{ }^{\circ} \mathrm{C}$. $\mathrm{pH}$ optimum for growth is 6.0-6.5; no growth above 8.0 or below $4 \cdot 5$. Obligate anaerobe. Complete inhibition by either $2 \%(\mathrm{w} / \mathrm{v}) \mathrm{NaCl}, 250 \mu \mathrm{g}$ sodium azide $\mathrm{ml}^{-1}$, or $100 \mu \mathrm{g}$ cycloserine $\mathrm{ml}^{-1}$, penicillin, streptomycin, tetracycline or chloramphenicol.

Metabolic characteristics. Chemoorganotroph. Utilizes a wide variety of compounds as energy sources including lactate, glucose, lactose, sorbitol, xylose, and amygdalin. Fermentation end products are propionic acid, acetic acid and carbon dioxide. Ethanol and succinate are formed under special conditions. Fumarate is reduced to succinate or propionate, but sulphate and nitrate are not reduced.

Habitat. Alkaline wetwoods associated with living poplar trees. Type strain 12B4. This strain was isolated from wetwood of a mature cottonwood tree located in Columbus, Wisconsin, U.S.A. and has been deposited in the American Type Culture Collection (ATCC 33732), Rock- 
ville, Md., U.S.A. and the Deutsche Sammlung von Mikroorganismen (DSM 2179), Göttingen, Germany.

This research was supported by the College of Agricultural and Life Sciences, University of Wisconsin and, in part, by grant DEB 7824071 from the National Science Foundation and by contract EY-79-5-02-2161 from the Department of Energy. We thank W. R. Kenealy for assistance in succinate measurement. B. Schink was supported by a grant from the Deutsche Forschungsgemeinschaft.

\section{REFERENCES}

BEIJERINCK, M. W. (1925). Über ein Spirillum, welches freien Stickstoff binden kann? Zentralblatt für Bakteriologie, Parasitenkunde, Infektionskrankheiten und Hygiene (Abteilung II) 63, 353-359.

Ben-BASSAT, A. \& ZeIKUS, J. G. (1981). Thermobacteroides acetoethylicus gen. nov. and sp. nov., a new chemoorganotrophic, anaerobic thermophilic bacterium. Archives of Microbiology 128, 365-370.

Bergmeyer, H. U. (1965). Methods of Enzymatic Analysis. Weinheim, F.R.G.: Verlag Chemie.

Buchanan, R. E. \& Gibbons, N. E. (1974). Bergey's Manual of Determinative Bacteriology, 8th edn. Baltimore: Williams \& Wilkins.

Davis, C. P., Cleven, D., Brown, J. \& Balish, E. (1976). Anaerobiospirillum, a new genus of spiralshaped bacteria. International Journal of Systematic Bacteriology 26, 498-504.

DELEY, J. (1970). Reexamination of the association between melting point, buoyant density, and the chemical base composition of deoxyribonucleic acid. Journal of Bacteriology 101, 738-754.

FerRy, J. G., Smith, P. H. \& Wolfe, R. S. (1974). Methanospirillum, a new genus of methanogenic bacteria and characterization of Methanospirillum hungatii sp.nov. International Journal of Systematic Bacteriology 24, 465-469.

HANKER, J. S. (1964). Osmiophilic reagent; new cytochemical principle for light and electron microscopy. Science 146, 1039-1043.

LeE, S. Y., Mabee, M. S. \& JangaARD, N. O. (1978). Pectinatus, a new genus of the Family Bacteroidaceae. International Journal of Systematic Bacteriology 28, 582-594.

MARMUR, J. (1961). A procedure for the isolation of deoxyribonucleic acid from microorganisms. Journal of Molecular Biology 3, 201-218.

Mayfield, C. I. \& INNISS, W. E. (1977). A rapid, simple method for staining bacterial flagella. Canadian Journal of Microbiology 23, 1311-1313.

Miller, G. L., Blum, R., Glenmore, W. E. \& BurTON, A. L. (1960). Measurement of carboxymethylcellulase activity. Analytical Biochemistry 1, 127-132.

Nelson, D. R. \& Zeikus, J. G. (1974). Rapid method for the radioisotopic analysis of gaseous end products of anaerobic metabolism. Applied Microbiology 28, 258-261.

NG, T. K., Weimer, P. \& Zeikus, J. G. (1977). Cellulolytic and physiological properties of Clostridium thermocellum. Archives of Microbiology 114, 1-7.

Postgate, J. R. (1963). Versatile medium for the enumeration of sulfate-reducing bacteria. Applied Microbiology 11, 265-267.

SchINK, B., WARD, J. C. \& ZeIKUS, J. G. (1981 $a$ ). Microbiology of wetwood: role of anaerobic bac- terial population in living trees. Journal of General Microbiology 123, 313-322.

Schink, B., WaRd, J. C. \& Zeikus, J. G. (1981 $b$ ). Microbiology of wetwood: importance of pectinolysis and Clostridium in living trees. Applied and Environmental Microbiology 42, 526-532.

SchwarTZ, A. C. \& Sporkenbach, J. (1975). The electron transport system of the anaerobic Propionibacterium shermanii: cytochrome and inhibitor studies. Archives of Microbiology 102, 261-273.

Stewart, W. D. P., Fitzgerald, G. P. \& Burris, R. H. (1967). In situ studies on $\mathrm{N}_{2}$ fixation using the acetylene reduction technique. Proceedings of the National Academy of Sciences of the United States of America 58, 2071-2078.

TARRAND, J. J., KRIEG, N. R. \& DöbereINER, J. (1978). A taxonomic study of the Spirillum lipoferum group with the descriptions of a new genus Azospirillum gen. nov. and two species Azospirillum lipoferum (Beijerinck) comb. nov. and Azospirillum brasiliense sp. nov. Canadian Journal of Microbiology 24, 967980.

DE VRIES, W., VAN WYCK-KaPTEYN, W. M. \& Stouthamer, A. H. (1973). Generation of ATP during cytochrome-linked anaerobic electron transport in propionic acid bacteria. Journal of General Microbiology 76, 31-41.

DE VRIES, W., VAN WYCK-KAPTEYN, M. C. \& OOSTERHUIS, S. K. H. (1974). The presence and function of cytochromes in Selenomonas ruminantium, Anaerovibrio lipolytica and Veillonella alcalescens. Journal of General Microbiology 81, 69-78.

ZEIKUS, J. G. (1980). Chemical and fuel production by anaerobic bacteria. Annual Review of Microbiology 34, 423-464.

ZeIKUS, J. G. \& BowEN, V. G. (1975). Fine structure of Methanospirillum hungatii. Journal of Bacteriology 121, 373-380.

ZeikUs, J. G. \& HenNing, D. L. (1975). Methanobacterium arbophilicum sp. nov., an obligate anaerobe isolate from wetwood of living trees. Antonie van Leeuwenhoek 41, 543-552.

ZeiKus, J. G. \& WaRD, J. C. (1974). Methane formation in living trees: a microbial origin. Science 184, $1181-1183$

Zeikus, J. G., Ben-Bassat, A. \& Hegge, P. W. (1980). Microbiology of methanogenesis in thermal volcanic environments. Journal of Bacteriology 143, 432-440.

Zeikus, J. G., HegGe, P. W. \& Anderson, M. A. (1979). Thermoanaerobium brockii gen. nov. and sp. nov., a new chemoorganotrophic, caldoactive, anaerobic bacterium. Archives of Microbiology 122, 4148. 